\title{
First Records of Limb Malformations in a Cane Toad, Rhinella marina (Anura: Bufonidae), and a Palm Rocket Frog, Rheobates palmatus (Anura: Aromobatidae), from Colombia
}

\author{
Juan Camilo Zuluaga-Isaza ${ }^{1}$, Mateo Marín-Martínez' ${ }^{1}$ Román Felipe Díaz-Ayala ${ }^{1}$, Julián Andrés Rojas-Morales ${ }^{2,3}$, \\ and Viviana Andrea Ramírez-Castaño ${ }^{1}$ \\ ${ }^{1}$ Grupo de Ecología y Diversidad de Anfibios y Reptiles, Facultad de Ciencias Exactas y Naturales, Universidad de Caldas, Manizales, Colombia \\ (juan_ah25@hotmail.com) \\ ${ }^{2}$ Ecología Tropical, Instituto de Ciencias Ambientales y Ecológicas, Facultad de Ciencias, Universidad de Los Andes, Mérida, Venezuela \\ ${ }^{3}$ Research Associate, "Museo de Historia Natural, Centro de Museos Universidad de Caldas, Manizales," Caldas, Colombia
}

$\mathrm{T}$ The steady increase of amphibian malformation records has attracted the attention of many researchers (e.g., Meteyer et al. 2000; Monroy-Vilchis et al. 2015) because the lack of corporal symmetry may be associated with a decline in amphibian populations (e.g., Pounds et al. 1997; Blaustein and Johnson 2003; Whittaker et al. 2013). Malformed frogs have been observed worldwide, although the number of South American records pale in comparison with those from North America and Europe, which have generated the greatest number of reports (Lannoo 2009). Factors that have been proposed as causes of incomplete or absence of limb development in amphibians include high UV-radiation exposure, deficient regeneration of injured extremities (caused by accidents or predators), pesticide abuse on agricultural crops, and, in some cases, helminthic parasite infections (e.g., Bohl 1997; Ankley et al. 1998; Alford and Richards 1999; Daszak et al. 1999; Johnson et al. 1999, 2002; Blaustein et al. 2003). Some studies have documented a great variety of deformities in amphibian populations, often affecting several species from different taxonomic groups (e.g., Read and Tyler 1990, 1994; Kiesecker et al. 2004; García-Muñoz et al. 2010). Malformations can include the emergence of additional limbs (polymelia) or the partial (ectromelia) or total (amelia) loss of them, which also can involve an increase (polydactyly) or decrease (ectrodactyly) in the number of digits (e.g., Ouellet et al. 1997, Johnson et al. 2001; Noronha et al. 2014; Ferreira et al. 2014; Monroy-Vilchis et al. 2015). In South America, Ouellet (2000), De Noronha et al. (2014), and Ferreira et al. (2014) reported from Venezuela, Brazil, and Argentina. Herein we provide the first report of polymely in a Cane Toad (Rhinella marina) and hemimelia in a Palm Rocket Frog (Rheobates palmatus) from two localities in the central
Andes of Colombia. Both individuals were collected and kept in the herpetological collection in the Museum of Natural History (Museo de Historia Natural) at the Universidad de Caldas (MHN-UCa).

On 17 August 2013 at 1930 h, we collected a juvenile R. marina (SVL $37.5 \mathrm{~mm}$; MHN-UCa 0774) in a pasture near banana and orange plantations in the Santágueda Sector,

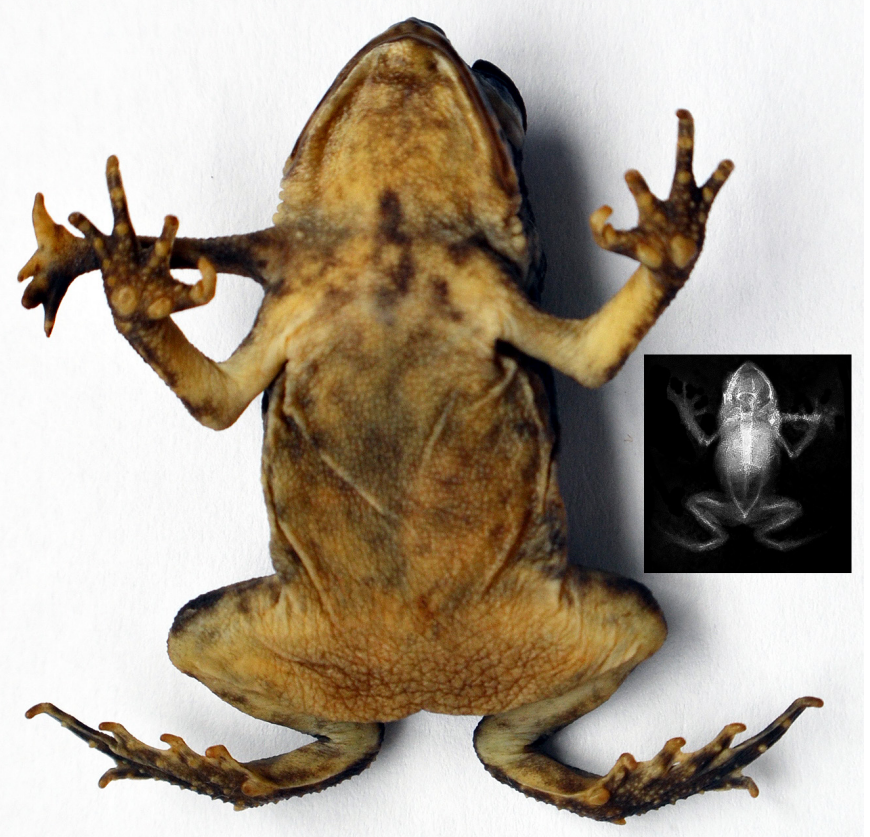

Fig. 1. A juvenile Cane Toad (Rhinella marina; $\mathrm{MHN}-\mathrm{UCa} 0774$; SVL = $37.5 \mathrm{~mm}$ ): Ventral view and (insert) a radiograph illustrating the articulation of the additional forelimb (Laboratorio de radiología, Hospital Veterinario de la Universidad de Caldas). Photograph by Juan Camilo Zuluaga. 
Palestina Municipality, Department of Caldas, Colombia $\left(05.0666^{\circ} \mathrm{N}, 075.6618^{\circ} \mathrm{W}\right.$; elev. $1,068 \mathrm{~m}$; WGS84). This individual had an additional forelimb (Fig. 1). A radiograph revealed that the toad did not have well-calcified bones, and that the additional arm apparently was inserted in the articulation of the right shoulder and was incompletely developed (Fig. 1).

On 27 May 2014, we collected an adult Palm Rocket Frog (R. palmatus; SVL 24 mm; MHN-UCa 0698) on rocky ground along a stream (Quebrada Negra) near Montebello Village, Norcasia Municipality, Department of Caldas, Colombia $\left(5.5757^{\circ} \mathrm{N}, 74.9231^{\circ} \mathrm{W}\right.$; elev. $850 \mathrm{~m}$; WGS84). This frog had a shortened left tibia-fibula (hemimelia; Fig. 2B) and an undeveloped first left finger (ectrodactyly; Fig. 2C).

These anomalies might be consequences of synergistic interactions of several factors, ultimately resulting in a genetic developmental disorder of the limbs (Blaustein et al. 2003; Bacon et al. 2013). The high incidence of UV-B rays and the negative action of chemical pollutants could be implicated. Deforestation in the Department of Caldas, primarily for creating pasture to raise livestock, has removed nearly $74 \%$ of the original vegetation cover (Rudas et al. 2007). This reduces forest canopy protection against UV rays along streams, where eggs and larvae develop. At the site where the $R$. palmatus was collected, in addition to possible genetic alterations due to a prolonged exposure to UV rays (Bacon et al. 2013), residues derived from livestock, agriculture, mining activities, and dumping of sewage from nearby farms might affect the genetic pool that regulates early hindlimb formation in metamorphs (Parr et al. 1998; Bacon et al. 2013), with negative consequences on the locomotive capacity of these individuals.

Palm Rocket Frogs are semiaquatic stream-dwellers, endemic to the Colombian Andes, where they inhabit rain and cloud forests at elevations of 300 to 2,400 m (Lüddecke 2003). Principal threats to the species are related to deforestation for agricultural development and pollution resulting from fumigation of crops (Ramírez et al. 2010). To our knowledge, malformations in this species have not been reported until now. Several malformation cases, however, have been reported for Cane Toads, with high UV radiation proposed as the principal cause (Bacon et al. 2013). These toads are explosive breeders that reproduce in both temporary and permanent ponds, often in open, frequently highly disturbed areas (Vargas-Salinas 2007). Such sites are vulnerable to several of the factors implicated in malformations (Bacon et al. 2013).

\section{Acknowledgements}

This work was possible thanks to permission granted by the regional environmental corporation Corporación Ambiental de Caldas (Corpocaldas; Resolution $N^{\circ} 164$ of 2014). We also are grateful to ISAGEN (contract 47/180) for funding
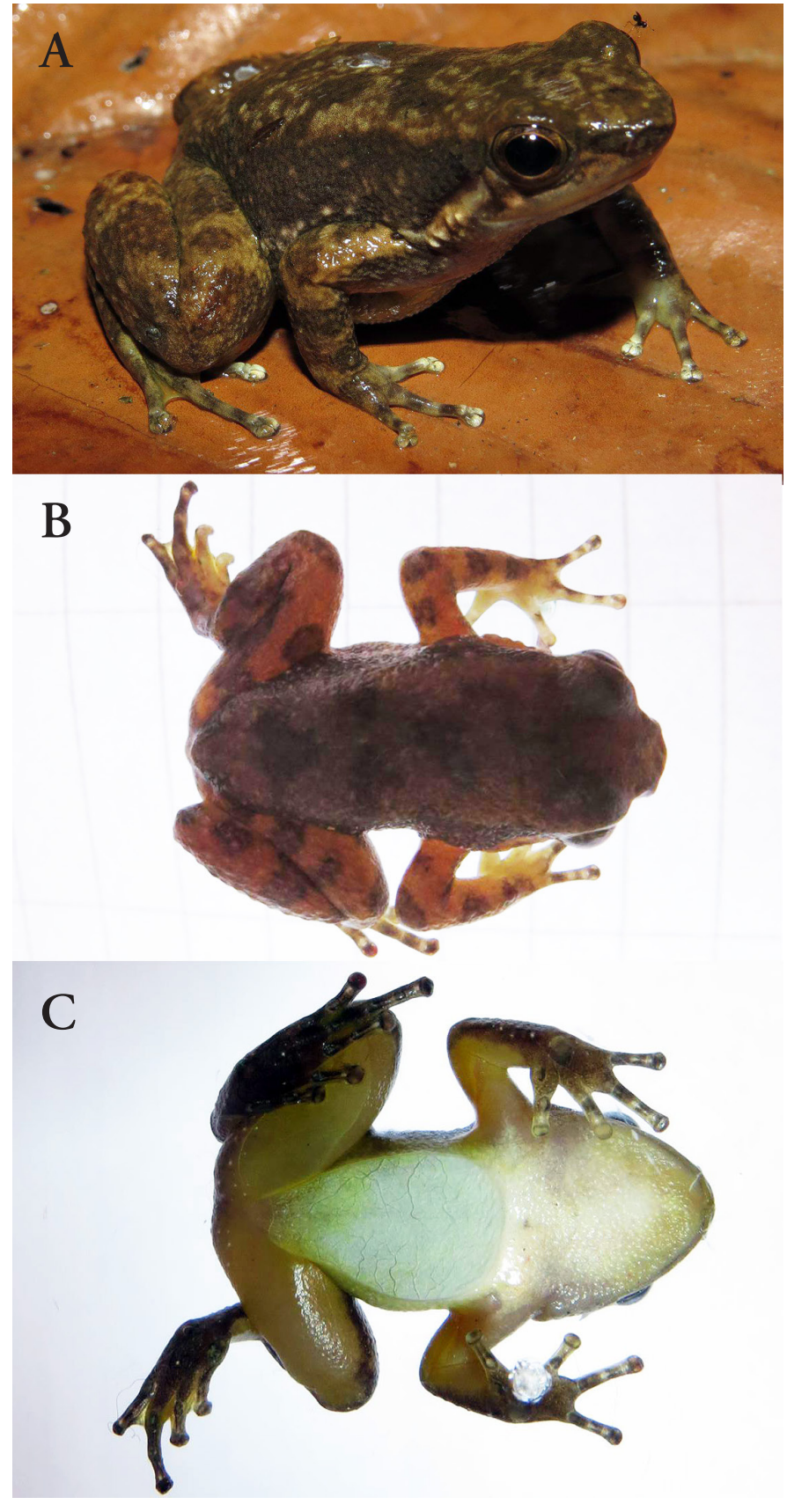

Fig. 2. A Palm Rocket Frog (Rheobates palmatus; MHN-UCa 0698; SVL $=24 \mathrm{~mm} ; \mathrm{A}$ ) with a shortened left tibia-fibula (hemimelia; dorsal view; B) and an undeveloped first left finger (ectrodactyly; ventral view; C). Photographs by Román Felipe Díaz.

part of the fieldwork and to Paul David Gutierrez for bibliographic and other valuable contributions.

\section{Literature Cited}

Alford, R.A. and S.J. Richards. 1999. Global amphibian declines: A problem in applied ecology. Annual Review of Ecology and Systematics 30: 133-165.

Ankley, G.T., J.E. Tietge, D.L. Defoe, K.M. Jensen, G.W. Holcombe, E.J. Durhan, and S.A. Diamond. 1998. Effects of ultraviolet light and methoprene on survival and development of Rana pipiens. Environmental Toxicology and Chemistry 17: 2530-2542. 
Bacon, J.P., C.E. Fort, B. Todhunter, M. Mathis, and D.J. Fort. 2013. Effects of multiple chemical, physical, and biological stressors on the incidence and types of abnormalities observed in Bermuda's Cane Toads. Journal of Experimental Zoology 320B: 218-237.

Blaustein, A.R. and P.T.J. Johnson. 2003. Explaining frog deformities. Scientific American 288: 60-65.

Blaustein, A.R., J.M. Romansic, J.M. Kiesecker, and A.C Hatch. 2003. Ultraviolet radiation, toxic chemicals and amphibian population declines. Diversity and Distributions 9: 123-140.

Bohl, E. 1997. Limb deformities of amphibian larvae in Aufseß (Upper Franconia): Attempt to determine causes. Munich Contributions to Wastewater Fishery and River Biology 50: 160-189.

Daszak, P. and A.A. Cunningham 1999. Extinction by infection. Trends in Ecology and Evolution 14: 279.

De Noronha, J.D.C., L.F. Barbosa, and D.D.J. Rodrigues. 2014. Lithobates palmipes (Green Rana). Forelimb malformation. Herpetological Review 45: 306.

Ferreira,R.B., C.Z. Zocca, M.M. Mageski, and F.C.F. Lírio. 2014. Rhinella crucifer (Sapo Cururuzinho; Striped Toad). Hinlimb malformation. Herpetological Review 45: 307.

García-Muñoz, E., F. Jorge, C. Rato, and M.A. Carretero. 2010. Four types of malformations in a population of Bufo boulengeri (Amphibia, Anura, Bufonidae) from the Jbilet Mountains (Marrakech, Morocco). Herpetology Notes 3: 267270 .

Johnson, P.T.J., K.B. Lunde, E.G. Ritchie, and A.E. Launer. 1999. The effect of trematode infection on amphibian limb development and survivorship. Science 284: 802-804.

Johnson, P.T.J., K.B. Lunde, E.G. Ritchie, J.K. Reaser, and A.E. Launer. 2001. Morphological abnormality patterns in a California amphibian community. Herpetologica 57: 336-352.

Johnson, P.T.J., K.B. Lunde, E.M. Thurman, E.G. Ritchie, S.N. Wray, D.R. Sutherland, J.M. Kapfer, T.J. Frest, J. Bowerman, and A.R. Blaustein. 2002. Parasite (Ribeiroia ondatrae) infection linked to amphibian malformations in the western United States. Ecological Monographs 72: 151-168.

Kiesecker, J.M., L.K. Belden, K. Shea, and M.J. Rubbo. 2004. Amphibian decline and emerging disease. American Scientist 92: 138-147.

Lannoo, M.J. 2009. Amphibian malformations, pp. 3089-3111. In: H.H. Heatwole and J.W. Wilkinson (eds.), Amphibian Biology. Amphibian Decline: Diseases, Parasites, Maladies and Pollution. Chipping Norton, Australia.
Lüddecke, H. 2003. Space use, cave choice, and spatial learning in the dendrobatid frog Colostethus palmatus. Amphibia-Reptilia 24: 37-46.

Meteyer, C.U., I.K. Loeffler, J.F. Fallon, K.A. Converse, E. Green, J.C. Helgen, S. Kersten, R. Levey, L. Eaton-Poole, and J.G. Burkhart. 2000. Hind limb malformation in free-living Northern Leopard Frogs (Rana pipiens) from Maine, Minnesota, and Vermont suggest multiple etiologies. Teratology 62: 151-171.

Monroy-Vilchis, O., L.L. Parra-López, T. Beltrán-león, J.A. Lugo, A. Balderas, and M.M. Zarco-Gonzáles. 2015. Morphological abnormalities in anurans from central Mexico: A case study (Anura: Ranidae, Hylidae). Herpetozoa 27: 115-121.

Ouellet, M., J. Bonin, J. Rodriguez, J. Desgranges, and S. Lair. 1997. Hindlimb deformities (ectromelia, ectrodactyly) in free-living anurans from agricultural habitats. Journal of Wildlife Diseases 33: 95-104.

Parr, B.A, E.J. Avery, J.A. Cygan, and A.P. Mcmahon. 1998. The classical mouse mutant postaxial hemimelia results from a mutation in the Wnt 7a gen. Developmental Biology 202: 228-234.

Pounds, J.A., M.P.L. Fogden, J.M. Savage, and G.C. Gorman. 1997. Tests of null models for amphibian declines on a tropical mountain. Conservation Biology 11: $1307-1322$.

Ramírez, M.P., M. Osorno-Muñoz, J.V. Rueda, A. Amézquita, and M.C. ArdilaRobayo, 2010. Rheobates palmatus. The IUCN Red List of Threatened Species 2010: e.T55124A11256311 (http://www.iucnredlist.org/details/ full/55124/0).

Read, J.L. and M.J. Tyler. 1990. The nature and incidence of post-axial, skeletal abnormalities in the frog Neobatrachus centralis Parker at Olympic Dam, South Australia. Transactions and Proceedings of the Royal Society of South Australia 144: 213-217.

Read, J.L. and M.J. Tyler. 1994. Natural levels of abnormalities in the Trilling Frog (Neobactrachus centralis) at the Olympic Dam Mine. Bulletin of Environmental Contamination and Toxicology 53: 25-31.

Rudas, G., M.D. Gordillo, D. Armenteras, N. Rodríguez, M. Morales, L.C. Delgado, and A. Sarmiento. 2007. Biodiversidad y actividad humana: relaciones en ecosistemas de bosque subandino en Colombia. Instituto de Investigación de Recursos Biológicos Alexander von Humboldt. Bogotá D.C., Colombia.

Vargas-Salinas, F. 2007. Breeding behavior of the Cane Toad Bufo marinus (Anura: Bufonidae), a successful invasive species. Herpetological Review 38: 12-17.

Whittaker, K., M.S. Koo, D.B. Wake, and V.T. Vredenburg. 2013. Global declines of amphibians, pp. 691-699. In: S.A. Levin (ed.), Encyclopedia of Biodiversity. Academic Press, Waltham, Massachusetts. 